\title{
Perineal hygiene in recurrent urinary tract infections - protective or predisposing?
}

\author{
DPCKA Lal \\ From 3rd International Conference on Prevention and Infection Control (ICPIC 2015) \\ Geneva, Switzerland. 16-19 June 2015
}

\section{Introduction}

Recurrent urinary tract infection is a common problem in pediatric clinical practice. Unsatisfactory perineal hygiene considered to be a main predisposing factor in theoretical background as the etiology of the condition is opportunistic microrganisms found in the perineal commensal microbiota. The impact of perineal hygiene on the occurence of urosepsis is not well studied in Sri Lankan community.

\section{Objectives}

The objective of this study is to evaluate the role of different perineal hygiene practices in recurrent urinary tract infections among Sri Lankan paediatric population.

\section{Methods}

45 female patients with recurrent urinary tract infections and age matched 45 controls were evaluated for perineal hygiene practices. All subjects were in the age of 1 to 5 years. Recurrent urinary tract infection was defined as 3 or more episodes of treated urosepsis within last one year period. Chi square test was used with the significance level of 0.05 for statistical analysis.

\section{Results}

Recurrent urinary tract infections were ecountered in 13, 04 and 28 children in the categories of washing with soap and water, washing with water and no washing respectively. Recurrent urinary tract infections were not found in 02, 21 and 22 children in the categories of washing with soap and water, washing with water and no washing respectively.

\section{Conclusion}

There is a statistically significant difference $(\mathrm{P}<0.05)$ of UTI occurrence among different perineal hygiene practices.

\footnotetext{
Surgery, National Hospital of Sri Lanka, Colombo, Sri Lanka
}

Washing with water seems to be protective whereas washing with soap and water seems to be predisposing.

Washing with water probably remove pathogenic microorganisms thereby preventing infections and washing with soap probably remove considerable amount of commensal organisms there by promoting colonization by pathogens. A prospective randomized controlled study with a bigger sample is recommended for more reliable information.

\section{Disclosure of interest}

None declared.

Published: 16 June 2015

\section{References}

1. Kamrul L, Eliza R, Habibura R, Ranjith R: Urinary Tract Infection in Children : An Update Bangaladesh. J Child Health 2012, 36(2):90-97.

2. Ahmed S. M., Avasarala A. K.: Urinary tract infections among adolescent girls in rural Kariminagar district. Indian J. Prev. Soc. Med 2009, 40(1 \& 2).

3. Stauffer C. M., van der Weg B., Donadini R.: Family history and behavioral abnormalities in girls with recurrent urinary tract infections: a controlled study. J Urol 2004, 171:1663.

doi:10.1186/2047-2994-4-S1-P263

Cite this article as: Lal: Perineal hygiene in recurrent urinary tract infections - protective or predisposing? Antimicrobial Resistance and Infection Control 2015 4(Suppl 1):P263.

Submit your next manuscript to BioMed Central and take full advantage of:

- Convenient online submission

- Thorough peer review

- No space constraints or color figure charges

- Immediate publication on acceptance

- Inclusion in PubMed, CAS, Scopus and Google Scholar

- Research which is freely available for redistribution 